\title{
伝統工芸産地における住居との関係からみた事業所の立地動向に関する研究 A STUDY ON LOCATION TREND OF WORKS FROM THE RELATION WITH
DWELLING-HOUSE AT TRADITIONAL CRAFT PLACE
}

\author{
小森宗 泰*, 野嶋 慎二** \\ Muneyasu KOMORI and Shinji NOJIMA
}

\begin{abstract}
This paper aims to clarify the location characteristic of works, the relation between works and dwellinghouse and the reason for selecting location of works founded in recent years.

Findings are as follows.

1.In Wajima-city, works are located in suburb in recent years. In Yamanaka-town, more works are located in suburb by construction of industrial complex.In Sabae-city, works are located in officially designated land.

2.There are much the works in which the house becomes one body in every city.

3.In Wajima-city, manager of works select the location by aiming at the improvement in the life.
\end{abstract}

Keyw ords:Traditional craft, Local city, Inner City, Industy Promotion, Living Environment, Residence 伝統工芸、地方都市、中心市街地: 産業振興、住環境、居住

\section{1. 研究の目的と方法}

全国の伝統工芸を持つ多くの都市では産業の衰退と後継者不足によ り産地全体としての活力が低下している。しかし、伝統工芸産地は単 に事業所が集積している工業団地ではない。古くから伝統工芸を生業 とした固有の生活文化を形成しており、これらを継承し街としての活 力を持続させていくことは歷史的にも地域資源の活用という視点から も重要な課題である。ここで伝統工芸産地の活力を持続していくため 次の $2 つ$ つ課題を考えたい。

第一に新規事業所の操業を維持していくための受け皿としての住宅 の課題である。一般に伝統工芸産業は零細な事業所により成立してお り、事業所と住居が一体となった職住一体型の事業所が多く、住宅は 事業所創業の重要な受け皿となっていると考えられる。これらの受け 四を供給していくには住宅供給サイドからの支援も重要である。

第二、郊外化による中心部の空洞化の課題である。これまでは産地 の問屋による流通経路が確立しており、郊外化しても事業が成立して いた。しかし、近年、これだけでは販売が困難であり、事業者が直接 産地で販売する仕組みが必要とされており、各地でその試みが行われ ている(1)。このとき中心市街地は、まちなか観光を行う来訪者にとっ ては購入の場であり、訪れる場である。事業所や住宅や店舗が複合し た伝統工芸産地としてのまちなみは地域文化を体感する重要な観光資
源となるが、郊外化によりこれらが失われている。

以上のように創業の場と居住の場を中心市街地で作り、中心市街地 の生活文化やまちなみを維持していくことは産地の活力再生のために は重要な要件の一つである。このためには産業振興施策だけでなく、 住環境の向上も含めた住宅施策やまちづくり施策との連帯した総合的 な施策が必要とされる。

本研究に関連する既存研究では、地場産業を対象としたツーリズム に関する研究りや伝統産業を地域資源とした地方都市における観光化 の手法に関する研究》、地場産業の事業所の立地動向と職住形態特性

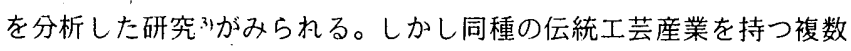
の産地について住扂との関係から事業所の立地動向を比較分析した研 究はみりられない。

以上のことから、本研究では、石川県、福井県の伝統工芸産地の中 から湶器産業を地域資源としている3 都市（輪島市、山中町、鯖江市 河田地区）を研究対象とし、事業所の郊外化の実態を明らかにする。 さらにその要因を業種特性と住宅立地との関係から明らかにし、住宅 が事業所の受け四として重要な役割を果たしていることを明らかにす ることで、産業振興施策と一体となった住宅施策を行うための基礎的 な知見を得ることを目的としている。このため以下の通りに論を進め る。

\footnotetext{
* 福井大学大学院工学研究科ファイバーアメニティ工学専攻 大学院生

Graduate Student, Dept. of Architecture, Faculty of Engineering, Fukui University

** 福井大学工学部建築建設工学科 助教授・博正 (工学) Assoc. Prof., Dept. of Architecture, Faculty of Engineering, Fukui University, Dr. Eng.
} 
第一に、輪島市、山中町、鯖江市河田地区、3 つの産地の業種特性 を明らかにする。さらに産地ごとに 1988 年以前と以降の創業に分類 して立地動向を分析することで、産地ごとの近年の郊外化の実態を明 らかにする。

第二に、産地ごとに事業所と住居の立地及び事業所に至る経緯を明 らかにし、住居との関係性を明らかにする。

第三に、近年創業した事業所について、職住形態別に立地場所の選 定理由を分析することで、産地ごとに住宅の立地がどのように事業所 の立地に影響しているかを明らかにする。

\section{2. 調查概要}

\section{(1) 対象都市の選定}

北陸 3 県 (富山県、石川県、福井県) で経済産業省の伝統的工芸品 目は 21 品目あり、その産地(は富山県で 4 都市、石川県で 6 都市、福 井県で 5 都市あり、北陸 3 県にとっても伝統工芸は重要な地域資源と なっている（表-1）。このうち漆器産業の産地が 6 都市あり、他の業 種に比べ最も多い。北陸 3 県の伝統工芸的品目のなかで企業数につい てみると輪島塗りが最も多く、山中漆器が 5 番目、越前漆器が 6 番目 に多くなっている。従業員数についてみると輪島塗りが最も多く、山 中漆器が 4 番目、越前漆器が 5 番目に多くなっている。これより漆器 産業は北陸3県の伝統工芸的品目のなかでも主要な産業であることが わかる。以上のことから漆器の産地である石川県輪島市（輪島塗り）、 石川県山中町（山中渌器）、福井県鯖江市（越前漆器）を対象都市と した。なお、表-2より、富山県高岡市 (高岡漆器)、石川県金沢市 (金 沢漆器)、福井県小浜市 (若狭塗り) は、事業所数、従業員数、生産 額が他産地と比べ著しく少ないため、対象外とした。

\section{（2）対象都市の業種特性}

溙器産業の業種を工程の内容から「販売工程」「加飾工程」「塗装工 程」「木地工程」の四つに分類した (3)。図 -1 をみると、輪島市、鯖江

表 -1 北陸 3 県の伝統工芸的品目の企業数 - 従業員数

\begin{tabular}{|c|l|r|r|}
\hline 品目 & \multicolumn{1}{|c|}{ 産地 } & 企業数(件) & 従業員数 (人) \\
\hline 輪島塗り & 石川県輪島市 & 813 & 2734 \\
\hline 九谷焼 & 石川県寺井町 & 400 & 1800 \\
\hline 高岡銅器 & 富山県高岡市 & 377 & 2688 \\
\hline 加賀友禅 & 石川県金沢市 & 359 & 940 \\
\hline 山中漆器 & 石川県山中町 & 280 & 1300 \\
\hline 越前漆器 & 福井県鯖江市 & 240 & 1265 \\
\hline 金沢泊 & 石川県金沢市 & 200 & 1000 \\
\hline 井波彫刻 & 富山県井波町 & 150 & 300 \\
\hline 越前打刃物 & 福井県武生市 & 101 & 269 \\
\hline 高岡漆器 & 富山県高岡市 & 92 & 235 \\
\hline 越前焼き & 福井県宮崎村 & 81 & 146 \\
\hline 金沢仏壇 & 石川県金沢市 & 61 & 133 \\
\hline 金沢漆器 & 石川県金沢市 & 50 & 100 \\
\hline 七尾仏壇 & 石川県七尾市 & 40 & 130 \\
\hline 越前和紙 & 福井県今立町 & 43 & 228 \\
\hline 庄川挽物木地 & 富山県庄川町 & 34 & 121 \\
\hline 越中和紙 & 富山県八尾町 & 10 & 91 \\
\hline 若狭塗 & 福井県小浜市 & 9 & 39 \\
\hline 牛首紬 & 石川県鶴来町 & 5 & 80 \\
\hline 加賀紼 & 石川県金沢市 & 5 & 100 \\
\hline 若狭めのう細工 & 福井県小浜市 & 5 & 8 \\
\hline & & & 50 \\
\hline
\end{tabular}

市では産地内の全事業所に対し販売業の事業所の占める割合が、それ ぞれ $58.5 \% 、 63.0 \%$ と最も大きい。これは、輪島市、鯖江市の販売業 のなかに塗装業も行う事業所も含まれているためである。山中町では 加飾業の事業所の占める割合が $26.9 \%$ と最も大きくなっており塗装業 (25.1\%)、木地業 $(24.0 \%)$ も高い割合を示す。輪島市、鯖江市は販 売業が多く、山中町では販売業よりも製造業を専門とした事業所が多 くなっていることがわかる。表-3をみると、1988 年以降に創業した 事業所の割合が最も大きい産地は鯖江市で $21.5 \%$ 、次いで輪島市が $11.3 \%$ 、最も割合が小さい産地は山中町で $6.2 \%$ となっている。業種別 にみると、輪島市では加飾工程が $16.0 \%$ と最も割合が大きく、山中町、 鯖江市では塗装工程がそれぞれ $13.0 \% 、 37.5 \%$ と最も割合が大きい。 これより、輪島市では加飾工程、山中町、鯖江市では塗装工程の事業 所が創業する傾向が強いことがわかる。

表 -2 漆器産地の事業所数·従業員数·生産額

\begin{tabular}{|c|c|c|c|c|c|c|}
\hline & \multicolumn{6}{|c|}{ 事業所数（件） } \\
\hline & 1995年 & 1996年 & 1997年 & 1998年 & 1999年 & 2000年 \\
\hline 輪島塗り & 792 & 769 & 734 & 699 & 667 & 657 \\
\hline 山中漆器 & 630 & 615 & 600 & 600 & 587 & 540 \\
\hline 越前漆器 & 332 & 329 & 325 & 314 & 298 & 295 \\
\hline 高岡漆器 & 101 & 101 & 101 & 99 & 92 & 92 \\
\hline 金沢漆器 & & 50 & 48 & 46 & 46 & 46 \\
\hline \multirow[t]{3}{*}{ 若狭塗り } & 15 & 13 & 10 & 10 & 9 & 9 \\
\hline & \multicolumn{6}{|c|}{ 従業買数 (人) } \\
\hline & 1995年 & 1996年 & 1997年 & 1998年 & 1999年 & 2000 年 \\
\hline 輪島塗り & 2512 & 2408 & 2303 & 2140 & 1967 & 1918 \\
\hline 山中漆器 & 4300 & 4000 & 3800 & 3500 & 3250 & 2900 \\
\hline 越前漆器 & 1309 & 1304 & 1295 & 1267 & 1168 & 1055 \\
\hline 高岡漆器 & 401 & 401 & 397 & 353 & 285 & 235 \\
\hline 金沢漆器 & & 69 & 67 & 60 & 60 & 58 \\
\hline \multirow[t]{3}{*}{ 若狭塗り } & 47 & 45 & 40 & 40 & 39 & 39 \\
\hline & \multicolumn{6}{|c|}{ 生産額（百万円） } \\
\hline & 1995年 & 1996年 & 1997年 & 1998年 & 1999年 & 2000年 \\
\hline 輪島鋈り & 10500 & 10000 & 9500 & 9000 & 8500 & 8000 \\
\hline 山中漆器 & 31500 & 31000 & 29000 & 26500 & 22500 & 20000 \\
\hline 越前漆器 & 12000 & 12000 & 11000 & 11000 & 9000 & 9000 \\
\hline 高岡漆器 & 1960 & 1780 & 1600 & 1400 & 1060 & 1030 \\
\hline 金沢漆器 & & 350 & 350 & 350 & 350 & 350 \\
\hline 若狭塗り & 72 & 70 & 60 & 60 & 50 & 45 \\
\hline
\end{tabular}

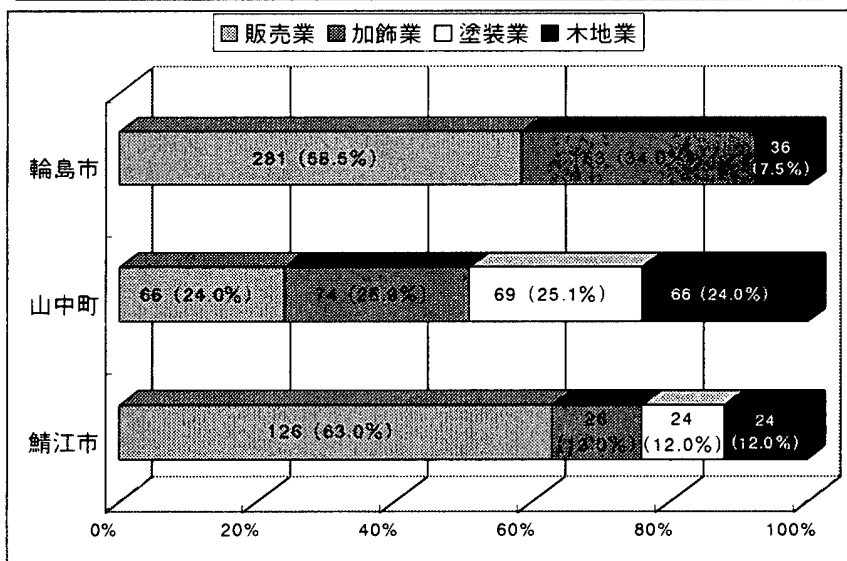

図-1 産地ごとの業種別事業所構成比

表 -3 産地ごどの業種別事業所件数

\begin{tabular}{|c|c|c|c|c|c|}
\hline & \multirow{2}{*}{ 販売業 } & \multicolumn{3}{|c|}{ 製造業 } & \multirow{2}{*}{ 合計 } \\
\hline & & 加飾 & 塗装 & 木地 & \\
\hline \multirow{2}{*}{ 輪島市 } & 281 & 163 & - & 36 & 480 \\
\hline & $28(10.0 \%)$ & $26(16.0 \%)$ & - & $0(0)$ & $54(11.3 \%)$ \\
\hline \multirow{2}{*}{ 山中町 } & 66 & 74 & 69 & 66 & 275 \\
\hline & $1(0.15 \%)$ & $4(5.4 \%)$ & $9(13.0 \%)$ & $3(4.5 \%)$ & $17(6.2 \%)$ \\
\hline \multirow{2}{*}{ 鯖江市 } & 126 & 26 & 24 & 24 & 200 \\
\hline & $23(18.3 \%)$ & $4(15.4 \%)$ & $9(37.5 \%)$ & $7(29.2 \%)$ & $43(21.5 \%)$ \\
\hline
\end{tabular}

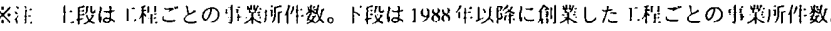

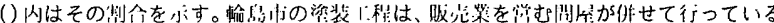




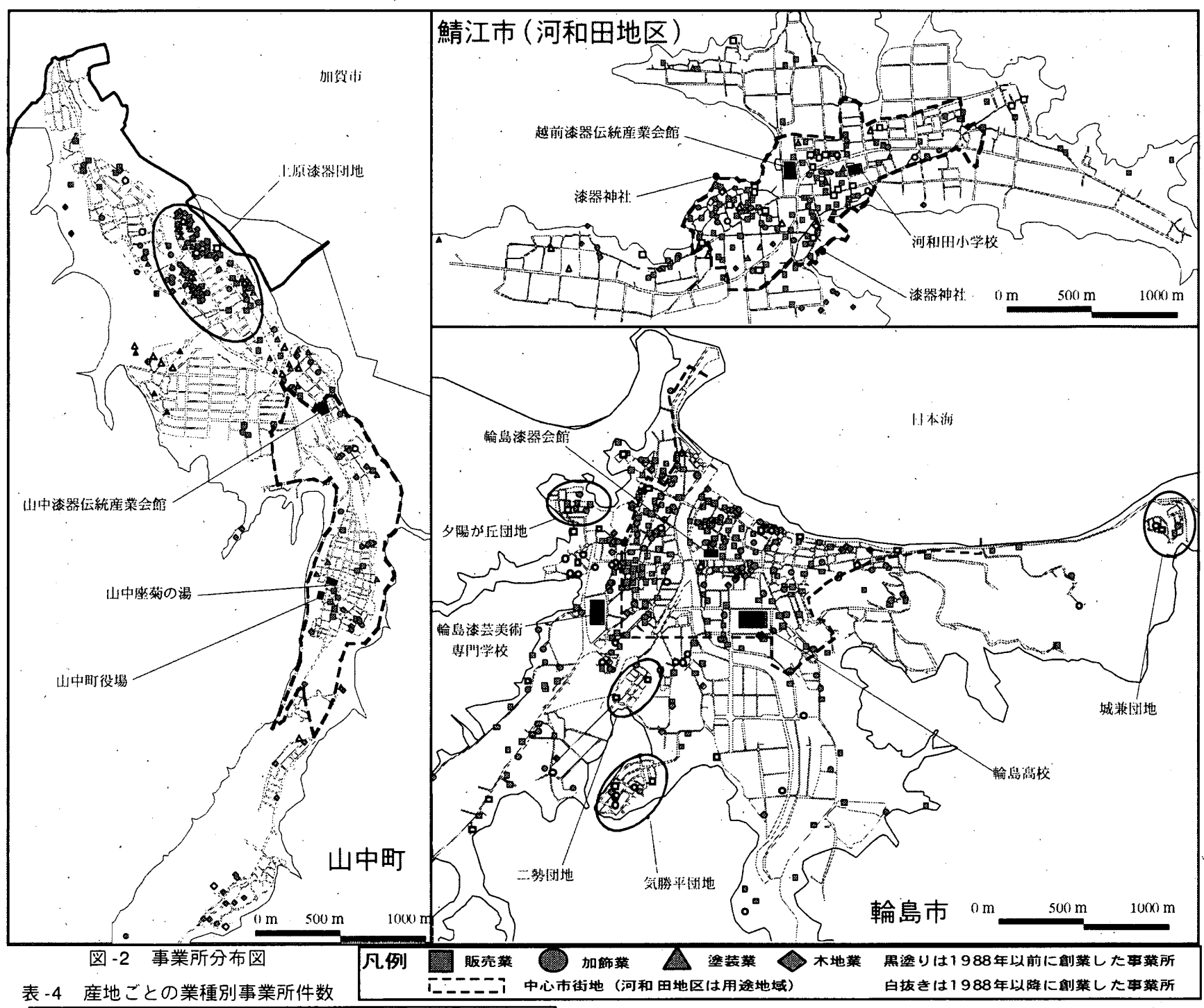

\begin{tabular}{|c|c|c|c|c|c|c|c|c|c|c|}
\hline & \multicolumn{3}{|c|}{ 俭昷市 } & \multicolumn{3}{|c|}{ 山中町 } & \multicolumn{3}{|c|}{ 解江市 } \\
\hline & & 中心市街地 & \begin{tabular}{|c|} 
中心节街地 \\
以外
\end{tabular} & 粉甜 & 中心市街地 & $\begin{array}{c}\text { 中心市街地 } \\
\text { 以外 }\end{array}$ & 棇湢 & 用途地域 & $\begin{array}{c}\text { 用途地域 } \\
\text { 以外 }\end{array}$ & 稳部 \\
\hline $\begin{array}{l}1 \\
9\end{array}$ & 眅 & $\begin{array}{c}15.7 \\
(62,1 \%)\end{array}$ & $\begin{array}{c}96 \\
(37.9 \%)\end{array}$ & 253 & $\begin{array}{c}19 \\
(29.2 \%)\end{array}$ & $\begin{array}{c}46 \\
(70.8 \%)\end{array}$ & 65 & $\begin{array}{c}96 \\
(93.2 \%)\end{array}$ & $\begin{array}{c}7 \\
(6.8 \%)\end{array}$ & 103 \\
\hline $\begin{array}{l}8 \\
\text { 年 }\end{array}$ & 妿 & $\begin{array}{c}69 \\
(50.4 \%)\end{array}$ & $\begin{array}{c}68 \\
(49.6 \%)\end{array}$ & 137 & $\begin{array}{c}20 \\
(28.6 \%)\end{array}$ & $\begin{array}{c}50 \\
(71.4 \%)\end{array}$ & 70 & $\begin{array}{c}.20 \\
(90.9 \%)\end{array}$ & $\begin{array}{c}2 \\
(9.1 \%)\end{array}$ & 22 \\
\hline 前 & 浩 & & & & $\begin{array}{c}10 \\
(16.7 \%)\end{array}$ & $\begin{array}{c}50 \\
(83.3 \%)\end{array}$ & 60 & $\begin{array}{c}15 \\
(100 \%)\end{array}$ & $\begin{array}{c}0 \\
10 \%)\end{array}$ & 15 \\
\hline $\begin{array}{l}* \\
L \\
E\end{array}$ & 木 & $\begin{array}{c}20 \\
(55.6 \%)\end{array}$ & $\begin{array}{c}16 \\
(44.4 \%)\end{array}$ & 36 & $\begin{array}{c}21 \\
(33.3 \%)\end{array}$ & $\begin{array}{c}42 \\
(66.7 \%)\end{array}$ & 63 & $\begin{array}{c}17 \\
(100 \%)\end{array}$ & $\begin{array}{c}0 \\
\{0 \%)\end{array}$ & 17 \\
\hline 新 & $\begin{array}{l}\text { 畣 } \\
\text { 計 }\end{array}$ & $\begin{array}{c}246 \\
(57.7 \%)\end{array}$ & $\begin{array}{c}180 \\
(42.3 \%)\end{array}$ & 426 & $\begin{array}{c}70 \\
(27.1 \%)\end{array}$ & $\begin{array}{c}188 \\
(72.9 \%)\end{array}$ & 258 & $\begin{array}{c}148 \\
(94.3 \%)\end{array}$ & $\begin{array}{c}9 \\
(5.7 \%)\end{array}$ & 157 \\
\hline $\begin{array}{l}1 \\
9\end{array}$ & 板 & $\begin{array}{c}4 \\
(14.3 \%)\end{array}$ & $\begin{array}{c}24 \\
(85.7 \%)\end{array}$ & 28 & $\begin{array}{c}0 \\
(0 \%)\end{array}$ & $\begin{array}{c}1 \\
(100 \%)\end{array}$ & 1 & $\begin{array}{c}19 \\
(82.6 \%)\end{array}$ & $\left(\begin{array}{c}4 \\
(17.4 \%)\end{array}\right.$ & 23 \\
\hline $\begin{array}{l}8 \\
8 \\
\text { 年 } \\
\text { 以 }\end{array}$ & 加 & $\begin{array}{c}5 \\
(19.2 \%)\end{array}$ & $\begin{array}{c}21 \\
(80.8 \%)\end{array}$ & 26 & $\begin{array}{c}1 \\
(25.0 \%)\end{array}$ & $\begin{array}{c}3 \\
(75.0 \%)\end{array}$ & 4 & $\begin{array}{c}4 \\
(100 \%)\end{array}$ & $\begin{array}{c}0 \\
10 \%)\end{array}$ & 4 \\
\hline 降 & 染 & & & & $\begin{array}{c}0 \\
.10 \%)\end{array}$ & $\begin{array}{c}9 \\
(100 \%)\end{array}$ & 9 & $\begin{array}{c}7 \\
(77.8 \%)\end{array}$ & $\begin{array}{c}2 \\
(22.2 \%)\end{array}$ & 9 \\
\hline 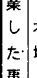 & 不 & 0 & 0 & 0 & $\begin{array}{c}0 \\
10 \%)\end{array}$ & $\begin{array}{c}3 \\
(100 \%)\end{array}$ & 3 & $\begin{array}{c}7 \\
(100 \%)\end{array}$ & $\begin{array}{c}0 \\
10 \%)\end{array}$ & 7 \\
\hline 亲 & $\begin{array}{l}\text { 合 } \\
\text { 竍 }\end{array}$ & $\begin{array}{c}9 \\
(16.7 \%)\end{array}$ & $\begin{array}{c}45 \\
(83.3 \%)\end{array}$ & 54 & $\begin{array}{c}1 \\
(5.9 \%)\end{array}$ & $\begin{array}{c}16 \\
(94.1 \%)\end{array}$ & 17 & $\begin{array}{c}37 \\
(86.0 \%)\end{array}$ & $\begin{array}{c}6 \\
(14.0 \%)\end{array}$ & 43 \\
\hline
\end{tabular}

(3) 調查方法

事業所立地に関するデータは、鯖江市・山中町では組合員名簿よ り、輪島市では 2000 年商工会議所登録データより得た。得られたデー 夕を基に1988年から2000年までまでの事業所の発生状況を調查した。 次に、電話帳より住居立地と職住形態に関するデー夕を得た ${ }^{(4)}$ 。さら に、2003 年 9 月から 11 月にかけて、過去 10 年間に創業した事業所に ヒアリングを行い、その発生要因に関するデータを得た。

\section{3. 産地ごとの事業所の立地動向}

産地ごとに事業所の立地動向を 1988 年以前と以降に分類して分析 を行う。

輪島塗りの事業所は、図2より市域全体に分布して立地している。 1988 年以降に創業した事業所 (白拔き) をみると、主に郊外部（以下、 中心市街地以外を郊外とする)に事業所の立地がみられる。郊外で は、夕陽が丘団地で 1 件、気勝平団地で 5 件、城兼団地で 2 件、二勢 団地で2件立地している。これらは、いずれも住宅団地であり、専用 住宅と共存しながら市域全体が就業の場となっていることがわかる。 表 3 より、1988 年以前に創業した事業所では、中心市街地 ${ }^{(5)}$ に立地 している事業所は販売 157 件 (62.1\%); 加飾 69 件 (50.4\%)、木地 20 件 (55.6\%) といずれも郊外よりもその割合が高い。これに対し 1988 
年以降に創業した事業所では、中心市街地に立地している事業所は販 売 4 件 (14.3\%)、加飾 5 件 (19.2\%)、木地 0 件と、中心市街地に立地 している事業所の割合が著しく低い。輪島市では 1988 年以降に侴業 した事業所は郊外に拡散していることがわかる。

山中漆器の事業所は、図2より中心市街地 (๙) よりも郊外に多くみ られ、なかでも上原漆器団地に集積している。山中町では、就業の場 が中心市街地ではなく郊外、特に上原漆器団地にあることがわかる。 1988 以前に創業した事業所 258 件のうち 78 件 (25.8\%) が上原漆器団 地 (7)に立地しているのに対し、1988年以降に創業した事業所 17件の うち4件 $(23.5 \%)$ が上原漆器団地に立地している。また、表4をみると、 1988 年以降に創業した事業所 17 件のうち中心市街地に立地している のは加飾業が 1 件のみであり、近年さらに郊外化が進行している。山 中町では、1988年以降も上原漆器団地が就業の場となっており、上原 漆器団地周辺に事業所が立地している。

越前漆器の事業所は、図2をみると用途地域内 ${ }^{\left({ }^{(}\right)}$に集積している。 なかでも河和田漆器神社周辺に集積している。鯖江市河和田地区で は、就業の場が用途地域内であることがわかる。表4より1988年以前 では $94.3 \%$ の事業所が用途地域内に立地している。また、1988年以降 に創業した事業所において用途地域内に立地している事業所が37件 (86.0\%)、用途地域外に立地している事業所が 6件 (14.0\%) となって おり、用途地域内での立地が多くみられる（図2）。これより鯖江市河 和田区では1988年以降も用途地域内が就業の場であることがわかる。

以上、漆器産業の事業所の立地は3地区でそれぞれ特色がみられる。 輪島市では近年事業所の郊外化が進行しており、住宅団地内に立地す る事業所が存在し、住宅地の郊外化とともに事業所の郊外化が進行し ている。山中町は漆器団地の建設によって郊外化が著しく進行してい る。鯖江市では、用途地域内で事業所が集積し、近年もその傾向がみ られる。

\section{4. 職住形態と職住距離}

（1）産地ごとの職住形態

各産地の職住形態をみると、表5より1988年以前に創業した事業所 のうち職住一体型事業所の割合は、輪島市で $87.2 \%$ と最も高く、次い
表 -5. 産地ごとの職住形態

\begin{tabular}{|c|c|c|c|c|c|c|c|}
\hline & \multicolumn{3}{|c|}{$\begin{array}{l}1988 \text { 年以前に } \\
\text { 創業した事業所 }\end{array}$} & \multicolumn{3}{|c|}{$\begin{array}{l}\text { 1988年以降に } \\
\text { 創業した事業所 }\end{array}$} \\
\hline & & 一体 & 分雊 & 計 & 一体 & 分離 & 計 \\
\hline \multirow{3}{*}{$\begin{array}{l}\text { 斛 } \\
\text { 島 } \\
\text { 市 }\end{array}$} & 中心市街地 & $\begin{array}{c}178 \\
(89.0 \%)\end{array}$ & $\begin{array}{c}22 \\
(11.0 \%)\end{array}$ & 200 & $\begin{array}{c}5 \\
(71.4 \%)\end{array}$ & $\begin{array}{c}2 \\
(28.6 \%)\end{array}$ & 7 \\
\hline & 中心市街地外 & $\begin{array}{c}129 \\
(84.9 \%)\end{array}$ & $\begin{array}{c}23 \\
(15.1 \%)\end{array}$ & 152 & $\begin{array}{c}34 \\
(89.5 \%)\end{array}$ & $\begin{array}{c}4 \\
(10.5 \%)\end{array}$ & 38 \\
\hline & 計 & $\begin{array}{c}307 \\
(87.2 \%)\end{array}$ & $\begin{array}{c}45 \\
(12.8 \%) \\
\end{array}$ & 352 & $\begin{array}{c}39 \\
(86.7 \%)\end{array}$ & $\begin{array}{c}6 \\
(13.3 \%)\end{array}$ & 45 \\
\hline \multirow{3}{*}{$\begin{array}{l}\text { 山 } \\
\text { 中 } \\
\text { 町 }\end{array}$} & 挂地 & $\begin{array}{c}43 \\
(87.8 \%) \\
\end{array}$ & $\begin{array}{c}6 \\
(12.2 \%) \\
\end{array}$ & 49 & $\begin{array}{c}0 \\
(0 \%)\end{array}$ & $\begin{array}{c}1 \\
(100 \%) \\
\end{array}$ & 1 \\
\hline & 中心市街地外 & $\begin{array}{c}83 \\
(76.9 \%) \\
\end{array}$ & $\begin{array}{c}25 \\
(23.1 \%) \\
\end{array}$ & 108 & $\begin{array}{c}7 \\
(58.3 \%) \\
\end{array}$ & $\begin{array}{c}5 \\
(41.7 \%) \\
\end{array}$ & 12 \\
\hline & 計 & $\begin{array}{c}126 \\
(80.3 \%) \\
\end{array}$ & $\begin{array}{c}31 \\
(19.7 \%) \\
\end{array}$ & 157 & $\begin{array}{c}7 \\
(53.8 \%) \\
\end{array}$ & $\begin{array}{c}6 \\
(46.2 \%) \\
\end{array}$ & 13 \\
\hline \multirow{3}{*}{$\begin{array}{l}\text { 鯖 } \\
\text { 江 } \\
\text { 市 }\end{array}$} & 用途地域内 & $\begin{array}{c}84 \\
(85.7 \%) \\
\end{array}$ & $\begin{array}{c}14 \\
(14.3 \%) \\
\end{array}$ & 98 & $\begin{array}{c}19 \\
(82.6 \%)\end{array}$ & $\begin{array}{c}4 \\
(17.4 \%) \\
\end{array}$ & 23 \\
\hline & 用途地域外 & $\begin{array}{c}24 \\
(88.9 \%)\end{array}$ & $\begin{array}{c}3 \\
(11.1 \%)\end{array}$ & 27 & $\begin{array}{c}8 \\
(66.6 \%)\end{array}$ & $\begin{array}{c}4 \\
(33.4 \%)\end{array}$ & 12 \\
\hline & 計 & $\begin{array}{c}108 \\
(86.4 \%)\end{array}$ & $\begin{array}{c}17 \\
(13.6 \%)\end{array}$ & 125 & $\begin{array}{c}27 \\
(77,1 \%)\end{array}$ & $\begin{array}{c}8 \\
(22.9 \%)\end{array}$ & 35 \\
\hline
\end{tabular}

注）上段は事業所件数。（）内は中心市街地、中心市街地外にそれそ征立地し ている全事業所数に対する職住一体型、職住分離型事業所の割合（鯖江市につ いては用途地域、用途地域外にそれそれ立地している全事業所数に対する睵住 一体型、職住分離型事業所の割台）を示す。

また、賰住形態が不明の事業所は除いてあるので表1、表4の台計数とは異なる。

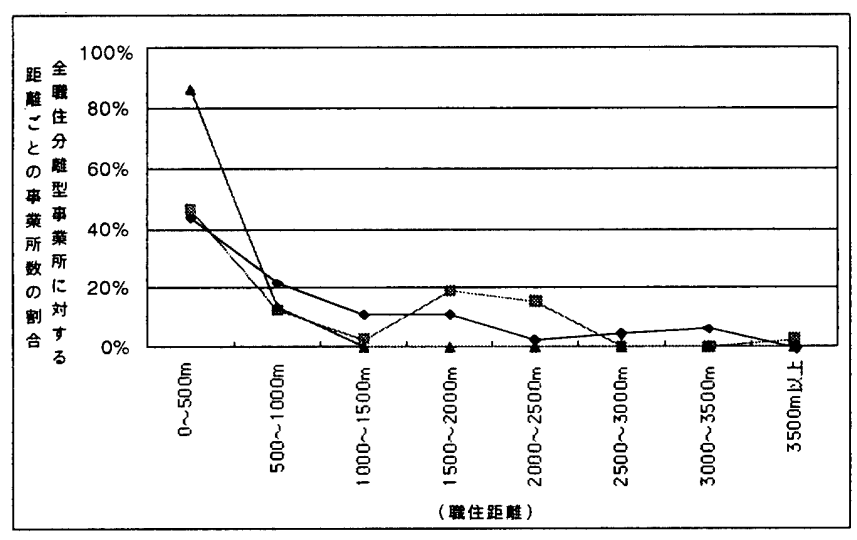

輪島市 一醉- 山中町 - 鯖江市

図 -3. 分離型事業所の職住距離

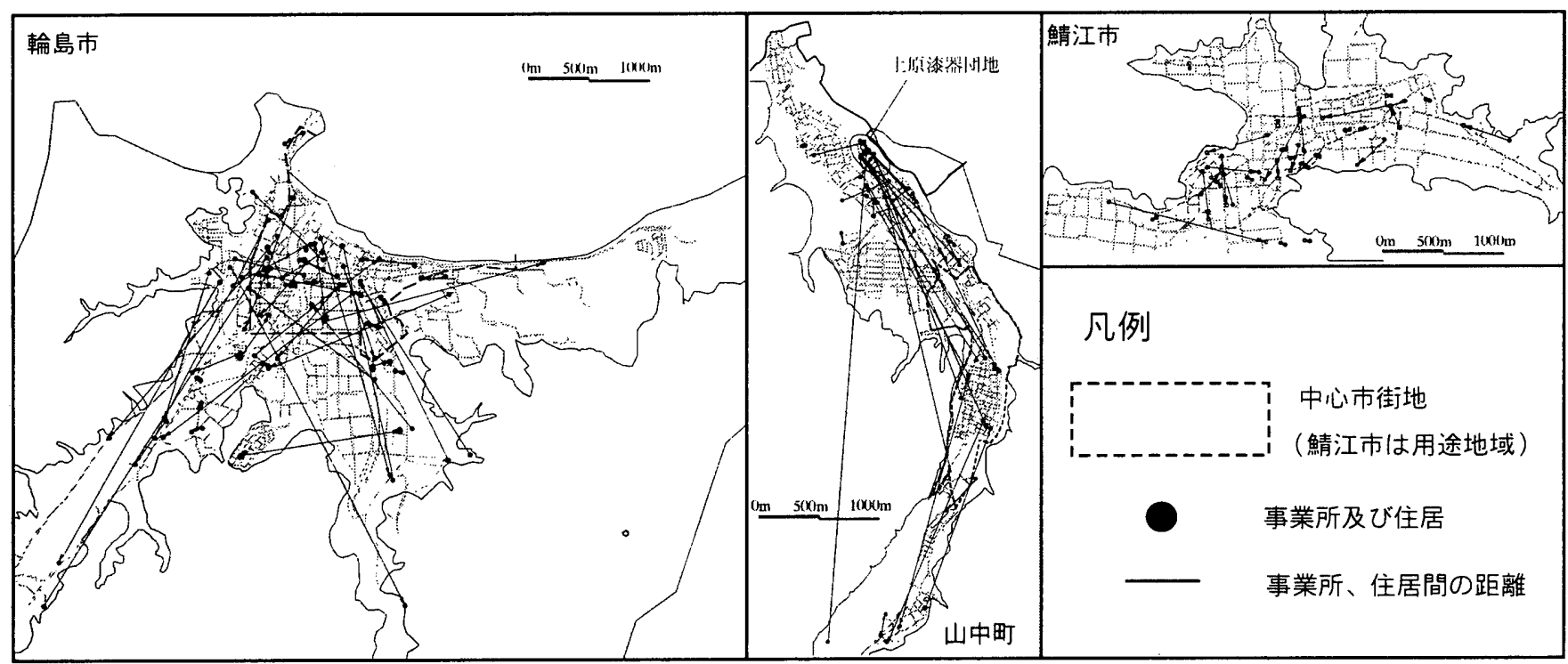

図 -4 職住分離型事業所の事業所と住居の分布図 
で鯖江市が $86.4 \%$ となっており、最も低いのが山中町で $80.3 \%$ となっ ている。いずれの産地においても職住分離型事業所よりも職住一体型 事業所の割合が多くなっている。1988年以降に創業した事業所のうち 職住一体型事業所の割合は輪島市で $86.7 \%$ と最も高く、次いで鯖江市 が $77.1 \%$ となっており、最も低いのが山中町で $53.8 \%$ となっている。

輪島市、鯖江市では職住一体型事業所の割合が高く、山中町では若 干低いという特性が続いている。

\section{(2) 職住分離型事業所の職住距離}

図3より,職住分離型事業所の事業所と住宅の距離（職住距離）をみ ると、産地内の全職住分離型事業所数に対して職住距離が $500 \mathrm{~m}$ 以内 の事業所数の割合が、輪島市で $44 \%$ 、山中町で $47 \%$ 、鯖江市で $86 \%$ となっており、いずれの産地でも職住距離が $500 \mathrm{~m}$ 以内で構成されて いる事業所が最も多いことがわかる。

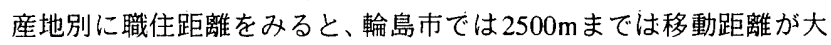
きくなるにつれて、事業所数が少なくなっている。山中町でも、 $1500 \mathrm{~m}$ までは、職住距離の拡大に伴い事業所数の減少がみられるが、 $1500 \mathrm{~m}$ 〜 2500m の間では事業所数が増加している。鯖江市では、 $1000 \mathrm{~m}$ 以上 の移動はみられない。輪島市、山中町では $1000 \mathrm{~m}$ 以上の職住距離もみ られることから、鯖江市の事業者は他都市に比べ職住距離が小さいこ とがわかる。

(3) 事業所と住居の立地関係

表 6.をみると輪島市では、中心市街地内での通勤が $25.5 \%$ 、中心市 街地から中心市街地外への通勤が $25.5 \%$ 、中心市街地外から中心市街 地への通勤が $21.6 \%$ 、中心市街地外での通勤が $27.5 \%$ となっており、 その割合に大きな差はみらられない。また、図4をみると輪島市では事 業主の住居は市域全域でみられ、市域全域で通勤が行われている。

山中町では、中心市街地内での通勤が $2.7 \%$.と最も少なく、郊外で の通勤が $59.5 \%$ と最も大きくなっている。また、図4より事業主の多 くが上原漆器団地へ通勤している。これより、仕事、生活の場はとも

\section{表 -6. 職住分離型事業所の事業所と住居の.立地}

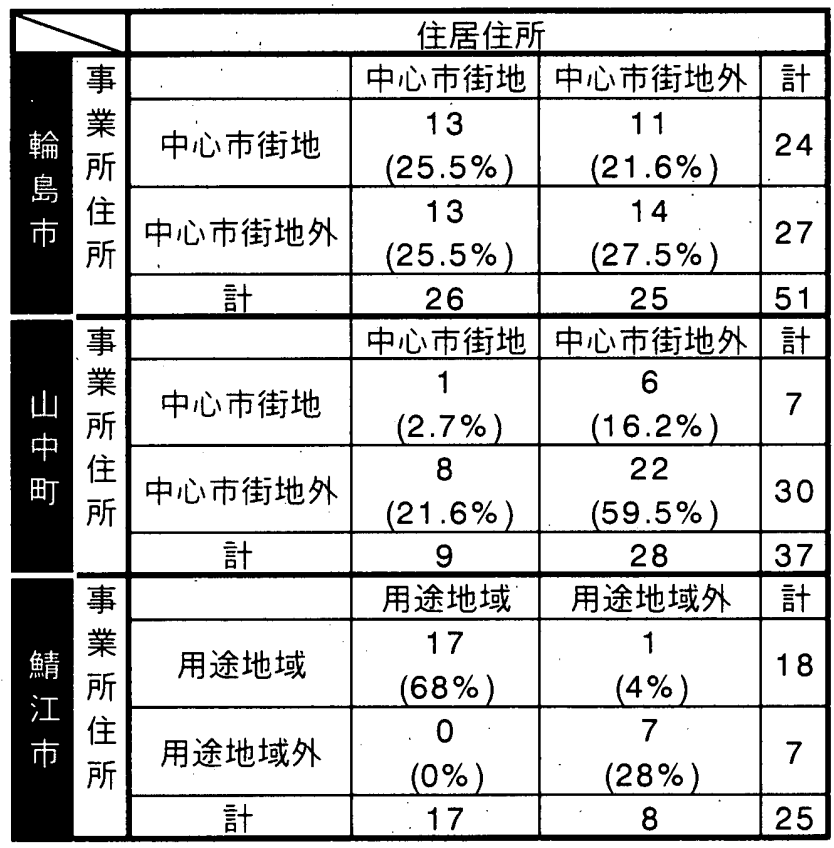

（注）上段は事業所件数。（）内は各産地内に立地している全事業所数に対す る職住分離型事業所の割合を示す。
に郊外であることがわかる。

鯖江市では、用途地域内での通勤が最も多く、用途地域内から用途 地域外や用途地域外から用途地域内への通勤は 1 件しかみらない（表 6、図 4)。事業所、住居ともに用途地域内に立地しており、用途地域 内が就業の場であり生活の場であることがわかる。

\section{5. 近年創業した事業所の場所選定理由}

近年創業した事業所についてどのような志向性で場所を選定してい るのかを分析する。

\section{（1）近年創業した事業所の概要}

表 7 よりヒアリングを行った事業所ば 114 件中 37 件である。表 8 よ り、輪島市では職住一体型が 11 件、職住分離型が 1 件、山中町では職 住一体型が 7 件、職住分離型が 2 件、鯖江市では職住一体型が 10 件、 職住分離型が 6 件となっている。

表 -7. ヒアリング件数

\begin{tabular}{|l|r|r|r|r|}
\hline & 輪島市 & 山中町 & 鯖江市 & 合計 \\
\hline 1988年以降に創業した事業所数 & 54 & 17 & 43 & 114 \\
\hline ヒアリングにより有効回答が得られた事業所数 & 12 & 9 & 16 & 37 \\
\hline
\end{tabular}

表 -8. 事業所の概要

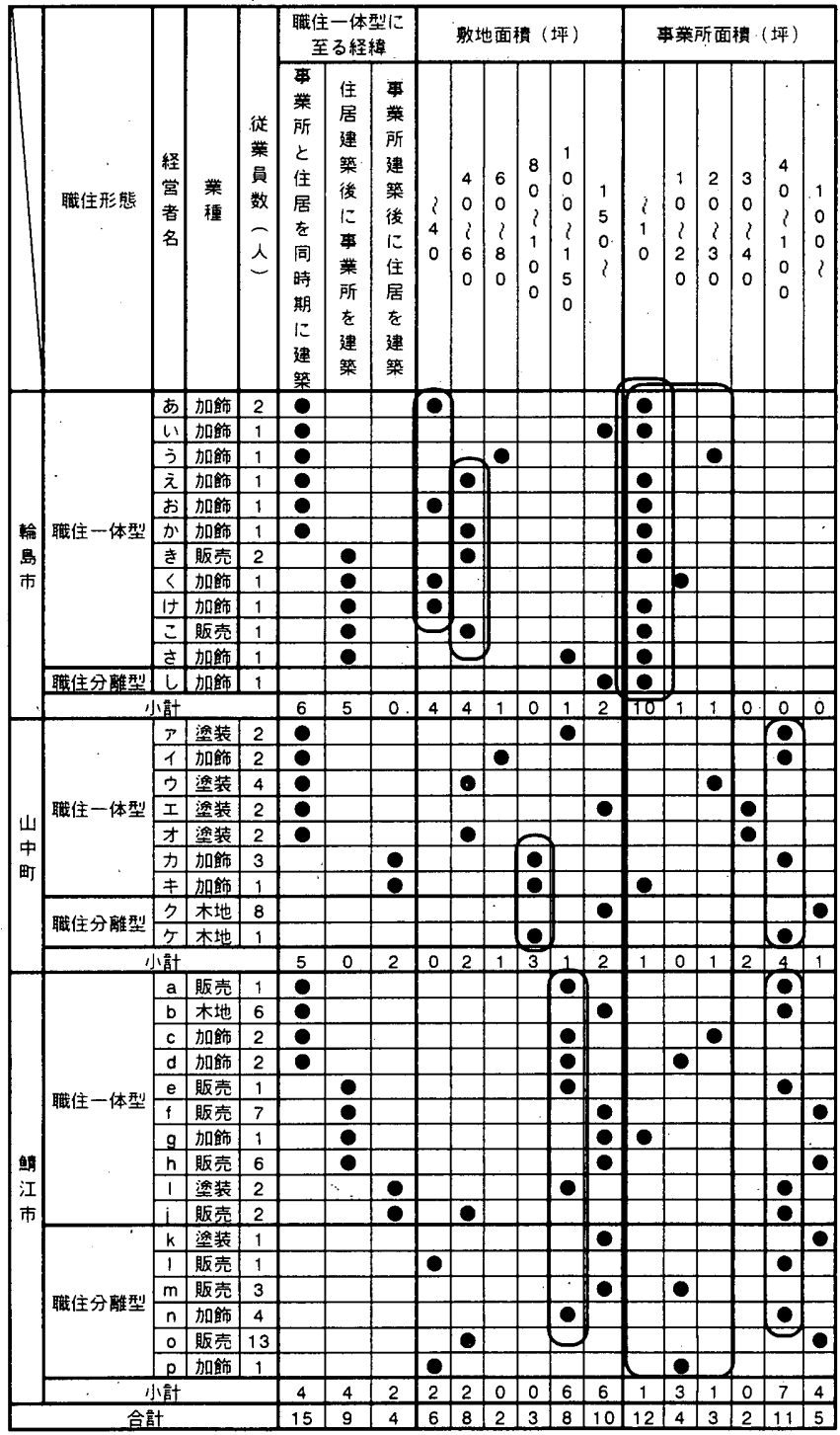

（注）経営者「あ」はアパートの一室にて事業を行っているため、敷地面積は貢 借している全部屋の面積、事業所面積は事業を行っている部屋の面積とした。 
表 8 より職住一体型に至る経緯をみると輪島市では「事業所と住居 を同時に建筑した」事業所が 6 件、「住居建築後に事業所を建築」した 事業所が5件となっており「事業所建築後に住居を建築」した事業所 はみられなかった。山中町では、「事業所と住居を同時に建築した」事 業所が 5 件、「事業所建築後に住居を建築」した事業所が 2 件、「住居 建築後に事業所を建築」した事業所はみられなかった。鯖江市で「事 業所と住居を同時に建築した」事業所が 4 件、「住居建築後に事業所を 建築」した事業所が 4 件、事業所建築後に住居を建築」した事業所が 2件となっている。3地区併せて「事業所と住居を同時に建築した」事 業所が 15 件、「住居建築後に事業所を建築」した事業所が9件、「事業

表-9、新規に創業した事業所の場所選定理由

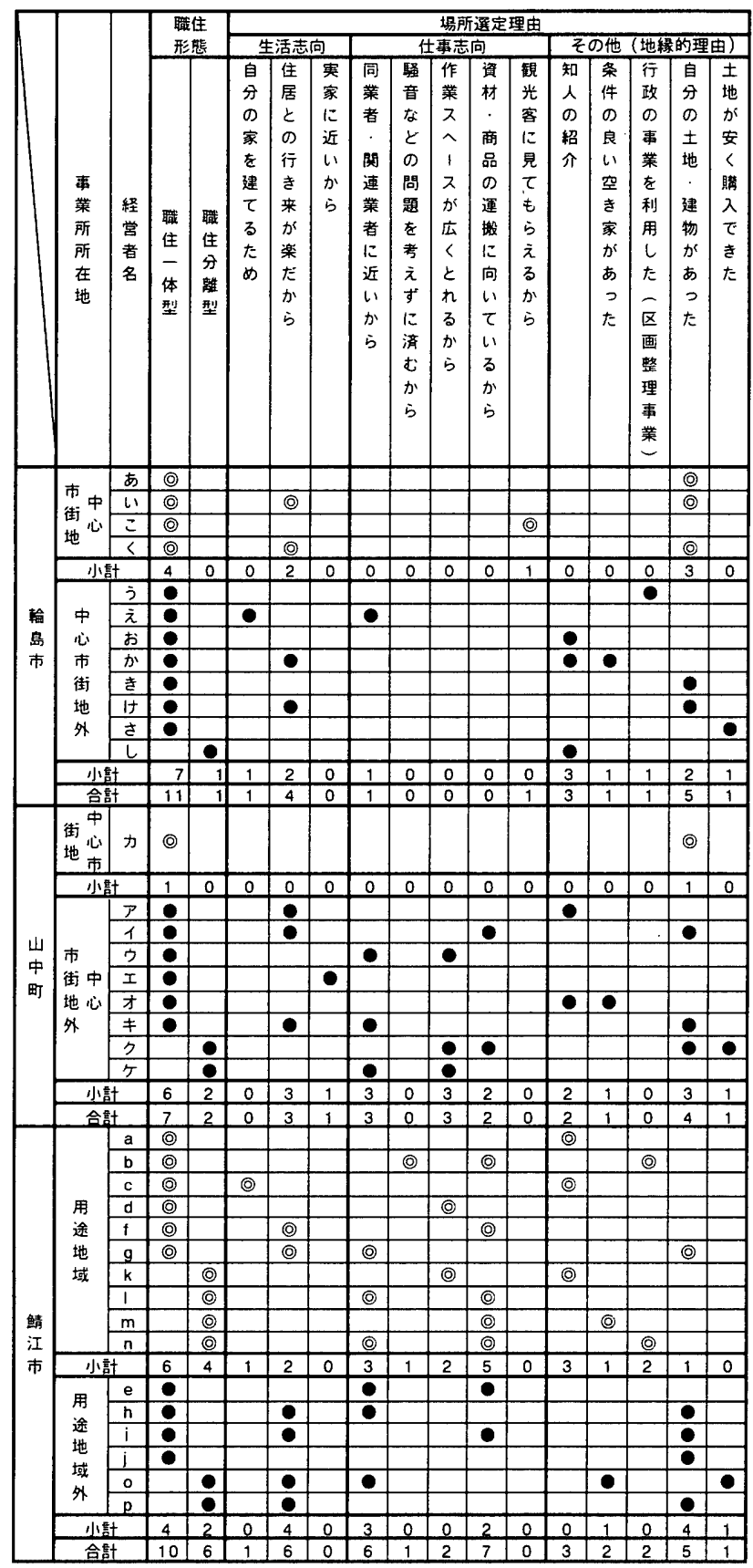

注）@は中心市街地（鯖江市については用途地域）に立地している事業所 のは中市街地外（鯖江市については用途地域外）に立地している事業所
所建築後に住居を建築」した事業所が 4 件となって扮り、「事業所建築 後に住居を建築」したパターンが最も少ない。これより瞕住一体型事 業所はまず住居の確立を行い、次に事業所をつくる傾向があり、職住 一体型事業所の立地には事業所以上に住居という生活基盤の立地選定 が影響していることがわかる。

次に、敷地面積をみると鯖江市では 100 ～150坪の事業所が16件中 6 件と最も多く、山中町では $80 \sim 100$ 坪の事業所が 9 件中 3 件と最も 多い。輪島市では 40 坪未満、40〜60坪の事業所がそれぞれ 4 件ずつ となっており最も多い。事業所面積をみると鯖江市、山中町共に40〜 100 坪の事業所が、それぞれ 16 件中 7 件、9 件中 4 件と最も多くなっ ている。輪島市では 10 坪末満の事業所が 12 件中 10 件と最も多い。鯖 江市は他の産地に比べ敷地、事業所面積ともに最も大きい。

以上よりピリングした37件のサンプル内の傾向だが、山中町は事 業所面積は最も大きいが、敷地面積は鯖江市よりも小さく、即ち事業 所に使う空間の割合が鯖江市に比べ大きい。また輪島市は敷地・事業 所面積ともに他の産地と比べて最も小さく、そのため場所の特性に関 わらず住宅団地やアパートなどに立地していると考えられる。

また、3地区全体でみて事業所面積が30坪末満の小規模な事業所 19 件のうち14件が加飾業者となっている。また、加飾業者の大半が從業 員が 1 人か 2 人と少ない。30坪以上の加飾業者は 3 件と少ない。これ より加飾業者は他の業種よりも事業所面積が小さいことがわかる。近 年創業した事業所 37 件のうち加飾業者が 18 件と最も多いのは、他の 業種に比べ事業所面積が小さくて済むことが要因の一つであると考え られる。また、輪島市は最も加飾業者が多く、住居内の一室で事業が 行えるため、住居の郊外化と連動して、事業所の郊外化が起こりやす くなっていると考えられる。

\section{(2) 場所選定理由}

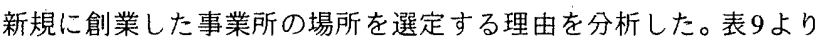
職住一体型事業所についてみると、輪島市(「あ、い、こ、く、う、え、 お、か、き、け、さ」)では、「自分の土地・建物があった」からとい う地縁的理由が 17 回答中 5 回答と最も多くなっている。次に多いのは 「住居との行き来が楽だから」という回答が17回答中 4 回答となって いる。また、「自分の土地・建物があった」という5件の回答のうち 3 件が「住居との行き来が楽だから」という回答をしている。これより、 輪島市では主に地縁的理由と「住居との行き来が楽だから」という生 活志向による選定理由で場所選定がなされていることがわかる。さら に場所選定理由を類型別にみると「その他」が 17 回答中 10 回答、「生 活志向」が 5 回答、「仕事志向」が 2 回答となっていることからも、仕 事志向よりも地縁的理由や生活志向により立地を選定している事業所 が多いことがわかる。

山中町（「力、ア、イ、ウ、エ、オ、キ」）では、「自分の土地・建 物があった」と「住居との行き来が楽だから」という回答が14回答中 3 回答と最も多い。場所選定理由を類型別にみると「その他」が 14 回 答中6回答、「生活志向」「仕事志向」が4回答ずつとなっており、「生 活志向」と「仕事志向」との間に差はみられなかった。

鯖江市（ra、b、c、d、f、g、e、h、i、j」）では、「自分の土地・建 物があった」「住居との行き来が楽だから」資材・商品の運搬に向い ているから」という回答がそれぞれ 21 回答中 4 回答ずつと最も多く、 次いで「同業者・関連業者に近いから」という回答が 21 回答中 3 回答 
となっている。場所選定理由を類型別にみると「仕事志向」が 21 回答 中9回答、「その他」が 7 回答、「生活志向」が 5 回答となっており、場 所選定時において生活志向よりも仕事志向により立地を選択している 回答が多い。また、「仕事志向」の割合を他の産地と比べると、鯖江 市で 21 回答中 9 回答、山中町で 14 回答中 4 回答、輪島市で 17 回答中 2 回答となっており、鯖江市が最も多い。鯖江市は、他の産地と比べ 仕事志向により立地を選択する傾向がある。

職住分離型事業所（経営者名「し」「ク、ケ」「 $\mathrm{k} 、 1 、 \mathrm{~m} 、 \mathrm{n} 、 \mathrm{o} 、 \mathrm{p} J$ ) についてみると、鯖江市では「同業者・関連業者に近いから」「資材・ 商品の運般に向いているからうという回答がそれぞれ 15 回答中3回答 ずつとなっており最も多い。類型別にみると、「仕事志向」が7回答、 「その他」が 6 回答、「生活志向」が 2 回答となっており職住分離型事 業所においては当然ではあるが仕事志向により立地を選択している が、かし生活志向で事業所立地を選定している事業所も存在してい る。

山中町では、「作業スベースが広くとれるから」という回答が6回答 中 2 回答と最も多い。類型別にみると「仕事志向」が 4 回答、「その他」 が 2 回答となっており「生活志向」による回答はみられなかった。山 中町の職住一体型事業所では 7 事業所中 4 事業所が生活志向により立 地を選択していることから、瞕住分離型事業所は職住一体型事業所よ りも「生活志向」により立地を選択する傾向は小さく、「仕事志向」に より立地を選択していることがわかる。

次に事業所の所在地別に分析する。輪島市では中心市街地に立地し ている事業所、中心市街地外に立地している事業所ともに「仕事志 向」により立地を選択している事業所はそれぞれ1件づつとなってい る。「仕事志向」よりも地緑的理由や「生活志向」により立地を選択 している事業所の方が多いという点で立地による差はみられない。

鯖江市の用途地域に立地している事業所（ $r^{a} 、 b 、 c 、 d 、 f 、 g 、 k 、$ l、m、n」) では「仕事志向」による回答が 21 回答中 11 回答と最も多 い。用途地域外に立地している事業所（「e、h、i、j、o、p」）では「そ の他」による回答が 15 回答中 6 回答と最も多く、次いで「仕事志向」 による回答が 15 回答中 5 回答となっている。少ないサンプル数での 傾向ではあるが、これより用途地域内に立地している事業所は、用途 地域外に立地している事業所よりも「仕事志向」により立地を選択す る傾向があることがわかる。

以上より、場所選定時おいて職住一体型事業所は瞕住分離型事業所 よりも生活志向により立地を選択する傾向がみられる。職住一体型事 業所では鯖江市では仕事志向により立地を選択する傾向がみられ、用 途地域内で事業所が集積しているメリットを求めている傾向がみられ る。山中町では地縁的理由をはじめとして生活、仕事、様々な理由で 場所を選定しており、これは漆器団地に集まる事業所の傾向であると 考えられる。輪島市では、他産地の職住一体型事業所と比べても生活 志向により立地を選択する事業所が多く、仕事志向よりも地縁的理由 や生活志向により立地を選択している。住宅の郊外化、住宅団地の郊 外開発が事業所の郊外化に大きな影響を与えていることがわかる。

\section{6. まとめ}

本研究は、石川県、福井県の漆器産地を研究対象とし、産地ごとの 業種特性と漆器関連事業所の近年の郊外化の実態を明らかにし、職住
形態や住宅立地や事業所の場所選定理由から住宅立地が事業所の郊外 化にどのように影響を与えているかについて産地ごとの特性を明らか にした。得られた知見は以下の通りである。

（1）輪島市は近年加飾業が多く創業している。加飾業は事業所面積が 小さく、住居内の一部で創業することも可能である。山中町は塗装業 や木地業が多く、鯖江市では塗装業が多く創業しており、山中町や鯖 江市は: 輪島市に比べて事業所規模が大きい。

（2）輪島市、山中町、鯖江市でそれぞれ事業所の立地動向に傾向がみ られた。輪島市では 1988 年以降事業所の郊外化が進行しており、郊 外の住宅団地内に創業する事業所も多くみられた。山中町では 1988 年以前から、漆器団地の建設に伴い郊外化が進行している。鯖江市で は用途地域内に事業所が集積し、創業もそこで行われている。 (3) 3 つの産地とも職住一体型の事業所の割合が8割を越えている。ま た職住分離型の事業所については、どの産地も事業所と住宅が $500 \mathrm{~m}$ 以内の近距離に立地している。しかし、輪島市では中心市街地と中心 市街地外、それぞれに事業所と住宅が同じ程度分散している。山中町 では、事業所と住宅がどちらも郊外に分散している。鯖江市では事業 所と住宅がどちらも用途地域内に集積している傾向がみられた。

(4) 職住一体型の事業所に至る経緯では、住宅の確立をまず行ってか ら事業所を創業する傾向があり、事業所立地も住宅の立地選定が大き く影響している。

（5）事業所の場所選定理由では、3地区とも「住居との行き来が楽だ から」など生活を志向して選定する事業所がみられる。事業所立地に 住宅の立地や生活環境が大きく影豐していることがわかる。

（6）輪島市は、特にその傾向が強く、加飾行程が多く、住宅内部でも 創業できるため、住宅の郊外化の影響を受けて事業所の郊外化が引き 起こされている。鯖江市では、仕事志向で立地を選定している事業所 も多く、用途地域内で集積する利点を求めている。

（7）以上のことから、郊外住宅は手軽に創業できる安価な事業所を提 供するという意味では創業の受け血としての役割を果たしている。し かし、中心部の空洞化という課題と来訪者のために地域文化を発信す る場として維持するためには、中心部での創業と住宅の立地は重要な 用件である。中心部の住環境の改善や住宅付きの工房長屋の供給など により創業者のための事業所と住宅の確保を行うなど、住宅施策によ る支援が必要である。

\section{脚注}

（1）例えば、鯖江市河和田地区の「漆のれん会」は気軽に漆を使ってもらうた め低価格で現地で販売する問屋や店舗のネットワーク組織である。

（2）経済産業省が主要製造地域としている地域を伝統的工芸品の産地とした。 また、主要製造地域が複数の地区にまたがる場台は、産地組台のある地区を産 地とした。

(3) 輪島市商工名鑑、山中漆器組台員名簿、越前漆器組台員名簿に分類されて

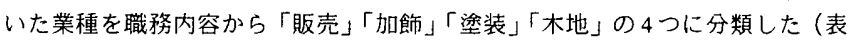
10)。

（4）山中町・鯖江市では組台買名簿より、輪島市では2000年商工会議所登録デー 夕より得ら机た事業主名、事業所住所のデータと電話帳に「個人名」として記 載されている氏名、住所とを比較唉討した。事業主名と電話帳に記載されてい る氏名が一致かつ事業所住所と電話帳に記載されている住所が一致したものを 「職住一体型事業所」とし、事業主名と電話帳に記載されている氏名が一致する ものの事業所住所と電話帳に記載されている住所が一致しないものを「職住分 離型事業所」とした。また、電話帳より事業主と同じ氏名が確認できなかった ものを「不明」とした。 
（5）「輪島市中心市街地活性化基本計画」により中心市街地と定められた区域に 設定した。その中心市街地は、中心商店街（本町商店街、わいち商店街、まん なか商店街、馬場崎商店会、駅前商店会、新橋）が含ま机小売業が集積してい る地域、人口密度が高く居住機能が集積している地域、都市機能が集積してい る地域という要素を考虑し設定されている。一方、研究の目的において中心市 街地は事業所や住宅や店舗が複合した伝統工芸産地のまちなみを通して地域文 化を体感できる地域であると定義しており妥当であると判断した。

(6)「山中町中心市街地活性化基本計画」により中心市街地と定められた区域に 設定した。その中心市街地は「山中座菊の湯」を中心としてそこから徒歩圏（概 ね $1 \mathrm{~km}$ 以内）で観光客が主に回遊している温泉地区を中心にした区域と設定さ れている。一方、研究の目的において中心市街地は来訪者が事業者との交流を 通し地域文化を体感できる地域であると定義しており妥当であると判断した。 （7）上原漆器団地は、山中漆器の量産体制の確立を図り1965 年に造成した。こ れにより中心市街地から上原漆器団地へと事業所が移転した。出典:「山中町史 現代編 1995 年発刊, pp301」

（8）「丹南都市計画（鯖江市）特別用途地区のあらまし」により用途地域と定め られている地域に設定した。

\section{参考文献}

1）佐久間康富、後藤春彦:「ファクトリー・ツーリズム」の可能性と限界一墨 田区におけるニット産業を事例として一 日本都市計画学会論文集,pp373〜 pp378,1999

2) 玉井明子、久隆浩: 伝統産業を軸としたイベント活動と観光まちづくりの円 滑化に関する一考察 日本都市計画学会論文集,pp271〜 pp276,1997

3）野嶋慎二：眼鏡関連産業の立地動向と職住形態特性に関する研究 第 14 回 環境情報科学論文集, pp373 pp378,1999

4）輪島市：輪島市中心市街地活性化基本計画，2000

5）山中町：山中町中心市街地活性化基本計画,2001

6）鯖江市：丹南都市計画（鯖江市）特別用途地区のあらまし,2001

7）山中町：山中町史現代編,1995

8）うるしの里づくり協議会：うるしの里づくりガイドライン ,1995

（2004年 2 月 10 日原稿受理，2004年 9 月 8 日採用決定
表 -10 産地ごとの業種の類型化

\begin{tabular}{|c|c|c|c|}
\hline & 輪島㴽 & 山中漆器 & 越前漆器 \\
\hline 木地 & $\begin{array}{c}\text { 角物木地 } \\
\text { 豊物木地 } \\
\text { 指物木地 } \\
\text { 朴木地 } \\
\text { 椀木地 } \\
\text { 研物 }\end{array}$ & $\begin{array}{l}\text { 成型 } \\
\text { 成函 } \\
\text { 木地 } \\
\text { 下地 }\end{array}$ & $\begin{array}{l}\text { 樹脂 } \\
\text { 木工 }\end{array}$ \\
\hline 塗装 & & 湟装 & 塗装 \\
\hline 加飾 & $\begin{array}{l}\text { 蒔絵 } \\
\text { 呂色 } \\
\text { 沈金 }\end{array}$ & $\begin{array}{c}\text { 上洒り } \\
\text { 蒔絵 }\end{array}$ & 加飾 \\
\hline 販売 & $\begin{array}{c}\text { 漆器製造 } \\
\text { 販売業 }\end{array}$ & 製造卸し & 製造販売 \\
\hline
\end{tabular}

